\title{
Does Economic Policy Uncertainty Affect Firm-level Financing in China?
}

\author{
Shun-yi Xiao* \\ School of Management \\ Beijing Normal University, Zhuhai \\ Zhuhai, China \\ shawsunny@foxmail.com
}

\author{
Chi-chuan Lee \\ School of Management \\ Beijing Normal University, Zhuhai \\ Zhuhai, China \\ leechichuan@bnuz.edu.cn
}

\begin{abstract}
This paper investigates the impacts of economic policy uncertainty (EPU) on firm-level financing with the fixed effect model, using quarterly panel data of the Shanghai and Shenzhen Stock Markets' A shares from 2003 to 2017. The results areas follows: (1) EPU has an unfavorable influence on firm-level financing. (2) Increases in firm growth, firm size, ROA, and GDP growth and a decrease in Tobin's $q$ significantly boost firm-level financing. Policy makers should thus maintain a stable economic policy, so that firms can firmly anticipate any economic policy and solidify their financing plans. Firms should also timely adjust decisions and behaviors according to changes in economic policy.
\end{abstract}

Keywords-Economic policy uncertainty; Firm-level financing; Fixed effect model; Micro-economic; Macro-economic

\section{INTRODUCTION}

The issue of economic policy uncertainty (EPU, hereafter) has generated considerable debate among financial economists. When confronting uncertain circumstances, economic entities will change their decisions and behaviors corresponding to such uncertainty. From the macroeconomic perspective, the global financial crisis that arose due to the U.S. subprime mortgage crisis in 2007 forced many in academia, industry, and government to pay more attention to the impact of uncertainty on economic entities. For instance, in April 2008 the U.S. Federal Open Market Committee (FOMC) emphasized that one of the key factors for the resulting dramatic decline in output and employment was uncertainty. From the microeconomic perspective, the shock from EPU is one of the main sources of firm risk, which can generate direct influences on enterprises' business operation modes and financial behaviors.

It is widely recognized that the impacts of EPU are pervasive, especially on firm-level financial decisions, which share a close relationship with economic policy. For example, the political election cycle usually brings about adjustments in economic reforms, resulting influctuating bank interest rates, which may discourage firms to borrow money from banks and thus influence their financing plans.

The $19^{\text {th }}$ Communist Party of China (CPC) National Congress held in 2017 clearly pointed out that China's economy has shifted from high-speed growth to high-quality development. In the vital stage of building a moderately prosperous society in all respects, building a modernized economic system is a strategic goal of China's development as

This paper is financially supported by the Guangdong Undergraduate Science and Technology Innovation Cultivation Special Fund.(Grant Number: pdjhb0598) well as an urgent need for the transition period. Real economy serves as a foundation of firms' development, and firms serve as important pillars of economic development. With China's economy entering a new normal stage, it is of vital significance for firms to make financial decisions by getting the utmost out of opportunities provided by economic development in the current uncertain environment.

This study explores the relationship between EPU and firmlevel financing, which differs from previous related studies focusing on macroeconomic uncertainty. What makes this paper unique is that we not only look at economic policy uncertainty by using the EPU index, but we also choose both microeconomic and macroeconomic variables to measure how EPU affects financing in a more complete scope. Through empirical analysis, we provide suggestions for government to stabilize policy making and advice to firms on financing when EPU appears, reducing the negative shock from EPU on financing decisions as much as possible.

\section{LITERATURE REVIEW}

A considerable amount of literature has been devoted to understanding the relationship between macroeconomic uncertainty and firm-level financial decisions. Even though the findings are abundant, there is only little knowledge about the interaction between EPU and firm-level financing.

Considering the determinants on firm leverage, Onofrei et al. [1] believe that tangibility, profitability and liquidity have negative impacts on leverage. $\mathrm{Qu}$ [2] find that the actual income taxation rate and firm size exert positive impacts on firm-level financing, while the collateral value of assets, profitability, and firm growth has negative impacts. Stiglitz and Weiss [3] note that firms face more challenges in financing constraints due to information asymmetry and financing agency costs. The studies have formed the empirical foundations for other later scholars to study the impact of uncertainty on financing.

From the viewpoint of macroeconomic uncertainty and firm-level financing decisions, Bernanke and Gertler [4] find that the former influences a firm's ability to borrow, and that weakly governed firms with high leverage are more likely to be credit constrained. Recent literature has investigated the relationship between uncertainty and firm-level financing from the empirical perspective. For example, Pastor and Veronesi [5] believe that uncertainty increases equity risk, reducing the 
demand for investment and financing. Baum et al. [6] establish a connection between non-financial firms' optimal level of short-term leverage and macroeconomic and idiosyncratic uncertainty, revealing that when macroeconomic and idiosyncratic uncertainty increases, firms will decrease their amount of short-term leverage, and the impact is stronger under macroeconomic uncertainty than idiosyncratic uncertainty. As for uncertainty, previous research mainly concentrates on macroeconomic uncertainty, such as policy uncertainty, rather than economic policy uncertainty, which correlate closer to firms' financing.

When it comes to economic policy uncertainty, Baker et al. [7] construct a measure for EPU and find negative effects of their uncertainty indices on investment, output, and employment in the U.S., mainly based on 10 large newspapers of a particular country as they relate to EPU. Gulen and Ion [8] and Li and Yang [9] use the EPU index compiled by Baker et al. to prove that EPU inhibits firm-level investment. The more severe the financing constraint is, the stronger the inhibiting effect will be. Lin and Ruan [10] creatively combine EPU with corporate financing. From the perspective of monetary supply, they confirm that if a listed company is non-state-owned, having a low return on investment (ROI), and is confronted by large financing constraints where the region is highly marketoriented, then EPU has a stronger inhibiting effect on actual financing.

Only a few research studies overall have focused on EPU, because there is no specific indicator on measuring it in the past. Scant scholars have even established a connection between EPU and firm-level financing. Thus, our paper fills this gap in the literature.

\section{ECONOMETRIC MODEL}

In this paper the dependent variable is actual firm-level financing $(\mathrm{F})$, the explanatory variable is economic policy uncertainty, and the control variables are Tobin's q (TQ), cash flow (CF), firm growth (SG), financial variables (X), and contemporaneous local macroeconomic conditions (M). To quantify financial variables and macroeconomic conditions, this paper chooses firm size and return on assets (ROA) on behalf of financial variables and inflation rate and the GDP growth rate on behalf of macroeconomic conditions. TableI provides all the detailed definitions of the variables in the empirical analysis.

Equation (1) is the benchmark specification, designed to investigate the impact of EPU on firm-level financing, where $i=1 \ldots \mathrm{N}, t=1 \ldots \mathrm{T}$, and $\mathrm{N}=3275$, which represents that the number of corporations is 3275 ; and $\mathrm{T}$ represents the sample period, ranging from 2003 Q1 to 2016 Q3. Since 2003, all Chinese listed companies have to report their financial statements on a quarterly basis as required by China Securities Regulatory Commission (CSRC).

$$
F_{i t}=\alpha_{i}+\beta_{1} E P U_{i t}+\beta_{2} T Q_{i t}+\beta_{3} C F_{i t}+\beta_{4} S G_{i t}+\gamma X_{i t}+
$$

TABLE I.

DEFINITIONS OF THE VARIABLES

\begin{tabular}{|l|l|}
\hline \multicolumn{1}{|c|}{ Variable } & \multicolumn{1}{c|}{ Definition } \\
\hline $\begin{array}{l}\text { Actual firm-level financing } \\
\text { (F) }\end{array}$ & $\begin{array}{l}\text { Ratio of cash flow from current } \\
\text { financing to total assets }\end{array}$ \\
\hline $\begin{array}{l}\text { Economic policy } \\
\text { uncertainty (EPU) }\end{array}$ & $\begin{array}{l}\text { Natural log of China EPU index, } \\
\text { compiled based on news by Baker et } \\
\text { al. (2016) }\end{array}$ \\
\hline Tobin's q (TQ) & $\begin{array}{l}\text { Ratio of stock market value to firm net } \\
\text { worth }\end{array}$ \\
\hline Cash flow (CF) & Ratio of net cash flow to total assets \\
\hline Firm growth (SG) & Prime operating revenue growth rate \\
\hline Firm size & Natural log of total assets \\
\hline Return on assets (ROA) & $\begin{array}{l}\text { Ratio of net revenue to average total } \\
\text { assets }\end{array}$ \\
\hline Inflation rate & $\begin{array}{l}\text { Change rate of consumer price index } \\
\text { (PPI) }\end{array}$ \\
\hline GDP growth rate & Sequential growth rate of GDP \\
\hline
\end{tabular}

The primary source of this study is the China Stock Market and Accounting Research (CSMAR) database for Tobin's q, cash flow, firm growth, financial variables, and some macroeconomic conditions. This paper uses quarterly panel data of the Shanghai and Shenzhen Stock Markets'A shares. Moreover, financial companies and "special treatment" shares are excluded in this paper so that companies with extremely high cash flow and abnormal financial conditions will not affect the empirical results. The Chinese EPU index is retrieved from Baker et al (2016). ${ }^{1}$

\section{EMPIRICAL RESULTS}

We adopt a fixed effects model to investigate the relationship between EPU and firm-level financing in China. TableII presents the estimation results of the basic model. The fixed effects regression model includes 102,426 panel observations over 15 years (2003-2017). Panel data contains observations of multiple phenomena over multiple time periods for different individuals, which includes more observations than traditional cross-sectional data and time-series data, thus providing more information, more changes, less collinearity and higher estimation efficiency. Fixed effects model is an important model for panel analysis, concentrating on differences within individuals. It can control for unobserved heterogeneity, which is constant overtime, and is correlated with independent variables, so that valid parameters are more accessible.

In order to eliminate the heteroscedasticity problem, EPU and Firm size are converted into natural log, so that the results can be more flexible and stable. The coefficients below suggest in the typical sample for China that the firm-level financing level is negatively influenced by the following indicators: EPU, Tobin's q, and it is positively related to firm growth, firm size, ROA, and GDP growth rate and to a lesser extent to cash flow and the inflation rate.

Regarding the fixed effects results, the coefficient of EPU are significantly and negatively correlated with actual firmlevel financing, indicating that increasing EPU hinders firmlevel financing. On the one hand, a majority of firms may hold up their financing plans when the economic policy is

Baker et al. (2016):www.policyuncertaincy.com 
ambiguous, as they cannot clearly predict what the monetary, financial, and income outcome will be like, which is consistent with findings in Lin and Ruan [10], Gu and Zhou [11]. On the other hand, Chen and Liu [12] proposition that EPU significantly decreases the trade credit of firms. Once the growth of EPU "hurts" firms' credit, it is difficult for them to seek a financing channel.

TABLE II. ESTIMATED RESULTS BASED ON THE FIXED EFFECTS MODEL

\begin{tabular}{|l|l|}
\hline \multicolumn{1}{|c|}{ Variable } & \multicolumn{1}{|c|}{ Fixed effects model } \\
\hline EPU & $-0.0333^{*}$ \\
& $(-2.3956)$ \\
\hline TQ (Tobin's q) & $-0.0171^{* * *}$ \\
& $(-16.1014)$ \\
\hline CF (Cash flow) & $1.06 \mathrm{E}-12$ \\
& $(0.4297)$ \\
\hline SG (Firm growth) & $0.0003^{* * *}$ \\
& $(15.9990)$ \\
\hline Firm size & $0.1125^{* * *}$ \\
& $(9.9639)$ \\
\hline ROA & $0.0315^{* * *}$ \\
& $(6.1646)$ \\
\hline Inflation rate & 0.5312 \\
& $(0.8102)$ \\
\hline GDP growth rate & $0.0640^{* * *}$ \\
& $(6.6245)$ \\
\hline Constant & $-2.0548^{* * *}$ \\
& $(-9.3108)$ \\
\hline F-test [p-value] & $43.9825^{* * *}$ \\
& {$[0.0000]$} \\
\hline Hausman test [p-value] & $1618.4799^{* * *}$ \\
& {$[0.0000]$} \\
\hline Observation & 102,426 \\
\hline \multirow{2}{*}{ Notes: t-values of the estimated coefficients are in parentheses.***,**, and * denote } \\
significance at the $1 \%, 5 \%$, and $10 \%$ levels, respectively. \\
\end{tabular}

The estimated results of control variables show reasonable results. The coefficients for firm growth, Firm size, ROA, and GDP growth rate prove overwhelmingly significantly positive that is, firms are more likely to conduct financing when firm growth is accelerating, firm size is expanding, and ROA and GDP growth rate are increasing. Firms may regard the situations above as signs indicating a bright future and thus be eager to branch out, enlarging the scale of financing. These findings are consistent with previous studies by Onofrei et al. [1], Qu [2], Kayo and Kimura [13], and Jensen [14].

It is noticeable that the coefficient of Tobin's $q$ is remarkably negative, which matches a previous study by Liu [15]. A high Tobin's q means a high return on investment, and the market value of shares issued by these enterprises is greater than the replacement cost of capital. Therefore, firms will improve liquidity of asset in order to grab the chance of arbitrage, thus weakening their finance needs. On the contrary, when Tobin's q decreases, firms will convert industrial capital into financial capital, preferring to hold or overweight stock shares, thus strengthening their financing needs.

At the bottom of TableII, the Hausman test serves as a means to see whether the fixed effect or the random effect is valid. The test rejects the random effects, because the statistics are suitable in one circumstance. Thus, this paper only reports the results employing the fixed effects model. The p-value of the F-test denotes that the entire regression equation is significant, demonstrating goodness of fit to the regression.

\section{Conclusions And Suggestions}

This paper explores the impacts of EPU and other factors on firm-level financing by carrying out the fixed effects model. The conclusions are as follows. (1) EPU does exert a significantly negative effect on firm-level financing. (2) Increases in firm growth, firm size, ROA, and GDP growth and a decrease in Tobin's q significantly raise firm-level financing.

On the basis of our findings, there are several considerations that have implication for the negative effect of EPU on firm-level financing. First, it is highly recommended that the China government establish a clearer economic policy implementation system by strengthening communications with firms through an information channel, thus letting financial markets know what policies the government is about to make, so that firms may predict the outcome of these policies as best as possible. The policies made as well as their execution should be more open and transparent. Nowadays, the best way for that is to connect firms with the government through the Internet. The government can announce policies online, and firms can receive the information in a timely manner, reducing the information asymmetry that may cause uncertainty. Second, firms should promptly adjust decisions and behaviors according to changes in economic policy. When facing EPU, firms should pay more attention to working capital management and improve asset liquidity to reduce risks.

\section{ACKNOWLEDGMENT}

This research is financially supported by the Guangdong Undergraduate Science and Technology Innovation Cultivation Special Fund (Grant Number: pdjhb0598).

\section{REFERENCES}

[1] M. Onofrei, M.B. Tudose, C. Durdureanu, and S.G. Anton, "Determinant factorsof firm leverage: An empiricalanalysis at Iasicounty level," Procedia Economics and Finance, vol.20, pp. 460-466, 2015.

[2] H. Qu, "Analysis on factors of fianancing decisions based on tobit regression model," On Economic Problems, vol.4, pp. 106-109, 2012.

[3] J.E. Stiglitz and A. Weiss, "Credit rationing in markets with imperfect information,” American Economic Review, vol. 71, pp. 393-410, 1981.

[4] B.S. Bernanke and M. Gertler, "Inside the black box: the credit channel of monetary policy transmission," Journal of Economic Perspectives, vol 9, pp. 27-48, 1995.

[5] L. Pastor and P. Veronesi, "Political uncertainty and risk premia," Journal of Financial Economics, vol. 7, pp. 520-545, 2013.

[6] C.F. Baum, A. Stephan, and O. Talavera, "The effects of uncertainty on the leverage of nonfinancial firms," Economic Inpuiry, vol. 47, pp. 216225, 23 April 2009.

[7] S.R. Baker, N. Bloom, and S.J. Davis, "Measuring economic policy uncertainty," The Quarterly Journal of Economics, vol. 131, pp. 15931636, 11 July 2016.

[8] H. Gulen and M. Ion, "Policy uncertainty and corporate investment," The Review of Financial Studies, vol. 29, pp. 1-55, 2016.

[9] F. Li and M. Yang, "Can economic policy uncertainty influence corporate investment? The empirical research by using China economic policy uncertainty index," Journal of Financial Research, vol. 4, pp. 115 129, 2015.

[10] J. Lin and M. Ruan, "Economic policy uncertainty and enterprise financing," Quarterly Journal of Finance, vol. 3, pp. 1-21, 2016.

[11] Y. Gu and Q. Zhou, "Policy uncertainty, value of financial flexibility and dynamic adjustment of capital structure," Journal of World Economics, vol. 6, pp. 103-126, 2018. 
[12] S. Chen and X. Liu, "Economic policy uncertainty and corporate trade credit extension," Journal of Financial Research, vol. 5, pp. 172-190, 2018.

[13] E.K. Kayo and H. Kimura, "Hierachical determinants of capital structure," Journal of Banking and Finance, vol. 2, pp. 358-371, 2011.
[14] M.C. Jensen, "Agency cost of free cash flow, corporate finance and takeovers," American Economic Review, vol.76, pp. 323-329, 1986.

[15] W. Liu, "A study on financial factors of the value of enterprises listed on SMEs board," Jiangnan University, June 2009. 